Ciência e Agrotecnologia 41(3):288-299, May/Jun. 2017

http://dx.doi.org/10.1590/1413-70542017413038516

\title{
Nutritional value of sorghum silage of different purposes
}

\author{
Valor nutritivo da silagem de sorgo de diferentes propósitos
}

\author{
Arthur Behling Neto ${ }^{*}$, Rafael Henrique Pereira dos Reis², Luciano da Silva Cabral ${ }^{3}$, \\ Joadil Gonçalves de Abreu ${ }^{3}$, Daniel de Paula Sousa ${ }^{4}$, Fabiano Gama de Sousa ${ }^{2}$
}

\author{
${ }^{1}$ Universidade Federal de Mato Grosso/UFMT, Instituto de Ciências Agrárias e Ambientais, Sinop, MT, Brasil \\ IInstituto Federal de Educação, Ciência e Tecnologia de Rondônia, Departamento de Pesquisa, Inovação e Pós-Graduação, Colorado do Oeste, RO, Brasil \\ ${ }^{3}$ Universidade Federal de Mato Grosso/UFMT, Faculdade de Agronomia e Zootecnia, Cuiabá, MT, Brasil \\ ${ }^{4}$ Universidade Federal de Mato Grosso/UFMT, Faculdade de Medicina Veterinária, Cuiabá, MT, Brasil \\ *Corresponding author: arthur_behling@hotmail.com \\ Received in October 1, 2016 and approved in February 2, 2017
}

\begin{abstract}
Sorghum is a crop that stands out as an alternative to corn due to lower soil fertility demand and increased tolerance to drought. Lack of information about the qualitative behaviour of sorghum hinders the recommendation of different purpose sorghum cultivars. The goal was to evaluate the chemical composition and in vitro digestibility of different purpose sorghum cultivar silages, at two cropping seasons. The trial was conducted at the Plant Production Department, Federal Institute of Education, Science and Technology of Rondônia, Colorado do Oeste campus, and chemical analyses and in vitro incubation were performed at the Laboratory of Animal Nutrition, Federal University of Mato Grosso, Cuiabá campus. The experimental design was a randomized block with a split-plot arrangement and four replications. Plot treatments consisted of six different purpose sorghum cultivars (BRS 308 and BRS 310, grain sorghum; BR 655 and BRS 610, forage sorghum; and BRS 506 and CMSXS 647, sweet sorghum). Split-plot treatments consisted of two cropping periods (first crop and second crop). Forage sorghum cultivar BRS 655 demonstrated higher non-fiber carbohydrate content and lower potentially digestible fibre content than the other cultivars did. Sweet sorghum cultivars had higher levels of water soluble carbohydrates and non-protein nitrogen based on protein, lower indigestible neutral detergent fibre content at second crop, and higher in vitro dry matter digestibility than the other cultivars. The silages of sweet sorghum cultivars BRS 506 and CMSXS 647, and forage sorghum cultivar BRS 655 presented higher nutritional values.
\end{abstract}

Index terms: Carbohydrate and protein fractions; chemical composition; ensiling; in vitro gas production.

\section{RESUMO}

O sorgo é uma cultura que se destaca como alternativa ao milho devido a menor exigência em fertilidade do solo e maior tolerância ao déficit hídrico. A falta de informações quanto ao comportamento qualitativo dificulta a recomendação de cultivares de sorgo de diferentes propósitos. Objetivou-se avaliar a composição bromatológica e a digestibilidade in vitro da silagem de cultivares de sorgo de diferentes propósitos, em duas épocas de cultivo. O delineamento experimental utilizado foi em blocos casualizados, com os tratamentos dispostos em esquema de parcela subdividida, com quatro repetições. Os tratamentos da parcela corresponderam a seis híbridos de sorgo de diferentes propósitos (BRS 308 e BRS 310, graníferos; BR 655 e BRS 610, forrageiros; BR 506 e CMSXS 647, sacarinos). Os tratamentos da subparcela corresponderam a duas épocas de cultivo (primeira safra e segunda safra). A cultivar de sorgo forrageiro BRS 655 apresentou maior teor de carboidratos não fibrosos e menor teor de fibra potencialmente digestível. As cultivares de sorgo sacarino obtiveram os maiores teores de carboidratos solúveis, os menores teores de fibra insolúvel em detergente neutro indigestível na segunda safra, e as maiores digestibilidades in vitro da matéria seca. As silagens de sorgo sacarino e de sorgo forrageiro BRS 655 apresentam maior valor nutritivo.

Termos de indexação: Fracionamento de carboidratos e proteína; composição bromatológica; ensilagem; produção de gás in vitro.

\section{INTRODUCTION}

Sorghum (Sorghum bicolor (L.) Moench) is a crop similar to corn in regards to its agronomic and nutritional value. However, in terms of requirements, sorghum is an attractive alternative to corn because it is more adapted to drought and low soil fertility (Borba et al., 2012). Among sorghum types are grain, forage, and sweet sorghum, which differ in plant height and nutritional value.
In Brazil, grain sorghum cultivars are usually recommended for high quality silage production because of their higher proportion of grains, whereas forage sorghum cultivars are recommended for high dry matter (DM) yield. Sweet sorghum has a high content of water soluble carbohydrates (WSC), resulting in forage with a high energy content (Kaiser et al., 2004). This type of sorghum is a good alternative for silage production because the DM yield is similar to forage sorghum, but with a higher WSC content 
(Zhang et al., 2015), which might allow the production of high quality silages. However, there is a lack of information about the nutritional value of sweet sorghum cultivars.

The nutritional value of feed is associated with its chemical composition and the utilization level of nutrients. Fractionation of carbohydrates and protein allows the formulation of appropriate diets, enabling maximum efficiency of energy and nitrogen use, both by microorganisms and by the animal (Sniffen; O’Connor; Van Soest, 1992). Besides the chemical composition, digestibility is a key parameter in the evaluation of forage quality. The in vitro procedure proposed by Tilley and Terry (1963) for determining the digestibility of food is the most widespread technique utilized in ruminant nutritional studies, owing to its low cost, quickness, and uniformity of results.

Studies on the use of grain sorghum for silage production are scare in Brazil. Forage sorghum cultivars, such as BRS 610 and BRS 655, have been studied for agronomic characteristics, chemical composition, and digestibility (Machado et al., 2012; Albuquerque et al., 2013; Santos et al., 2013), as have some cultivars of sweet sorghum, such as BRS 506 (Gomes et al., 2006; Orrico Junior et al., 2015). However, evaluations of nitrogen and carbohydrates fractions, as well as kinetics parameters are rare in sorghum silage evaluations.

Besides the cultivar, the crop period might influence grain production and cause variations in panicle proportion and nutritional value of forage. Studies have demonstrated that corn production at second crop presents higher problems with grain filling and yield compared to the first crop (Farinelli et al., 2003; Heinemann et al., 2009). Regarding sorghum, which is more tolerant to water deficit, there is little information about the effect of the growing season on the forage chemical characteristics and its influence on the silage nutritional value.

Thus, the goal was to evaluate the nutritional value of different purpose sorghum silage cultivars at two crop periods.

\section{MATERIAL AND METHODS}

\section{Experimental conditions}

The trial was conducted at the Plant Production Department, Federal Institute of Education, Science, and Technology of Rondônia, Colorado do Oeste campus, and chemical analyses and in vitro incubation were performed at the Laboratory of Animal Nutrition, Federal University of Mato Grosso, Cuiabá campus. The soil in the experimental area was a typical eutrophic red ultisol. The climate was Awa, based on the Köppen classification system, with an average temperature of $27^{\circ} \mathrm{C}$ and annual average rainfall of 1497 $\mathrm{mm}$. The rainfall data was collected from the meteorological station of Vilhena-RO, Brazil (INMET, 2016), located approximately $70 \mathrm{~km}$ from the experimental area (Figure 1).

\section{Experimental design and treatments}

The experimental design was a randomized block with a split-plot arrangement and four replications. Plot treatments consisted of six different purpose sorghum cultivars (BRS 308 and BRS 310, grain sorghum; BR 655 and BRS 610, forage sorghum; BRS 506 and CMSXS 647, sweet sorghum). The split-plot treatments comprised two crop periods (first crop and second crop).

For the first crop, seeding was performed on November 3, 2011, while for the second crop, seeding occurred on March 22, 2012. The spacing between lines

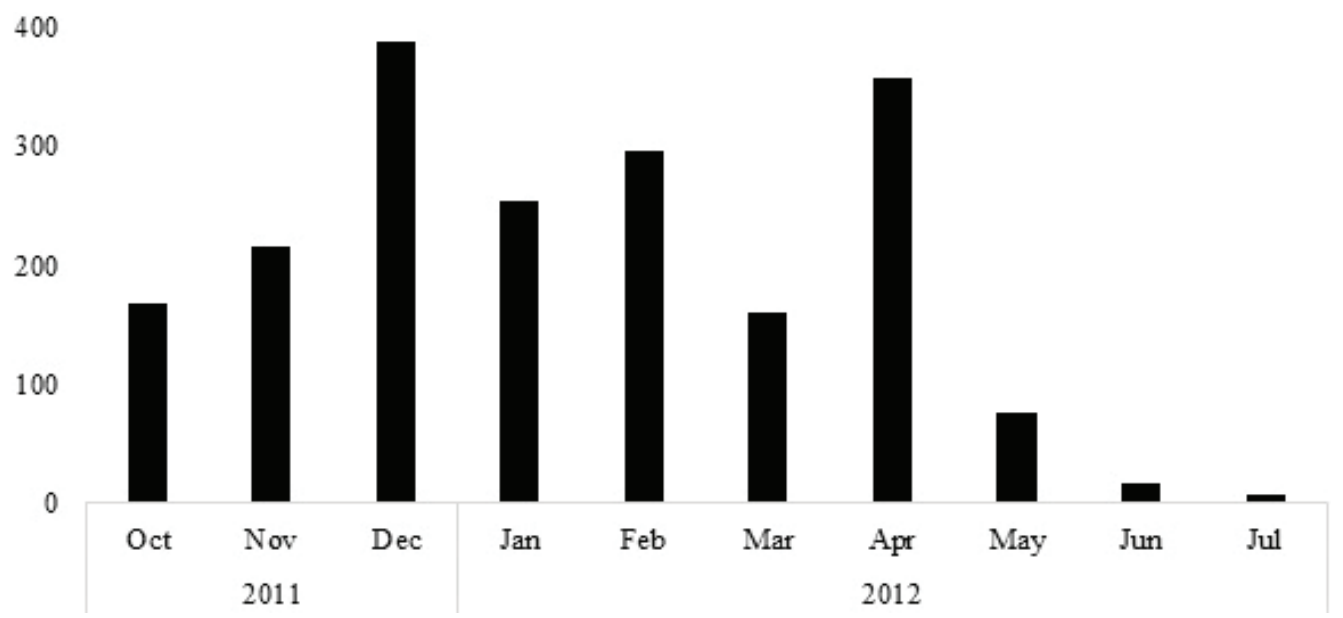

Figure 1: Monthly values of rainfall during the trial period, October 2011 to July 2012. 
was $0.60 \mathrm{~m}$, with density of 180,000 plants ha ${ }^{-1}$ for grain sorghum cultivars, and 120,000 plants ha ${ }^{-1}$ for cultivars of forage and sweet sorghum. The plot consisted of four planting lines $5 \mathrm{~m}$ in length. A $0.5 \mathrm{~m}$ border was reserved around the entire perimeter of the study plot, reducing the usable area to two central rows, each of them $4 \mathrm{~m}$ in length. At seeding for both crops, fertilizer was applied at doses of $20 \mathrm{~kg} \mathrm{ha}^{-1} \mathrm{~N}, 40 \mathrm{~kg} \mathrm{ha}^{-1} \mathrm{P}_{2} \mathrm{O}_{5}$ and $60 \mathrm{~kg} \mathrm{ha}^{-1} \mathrm{~K}_{2} \mathrm{O}$ using urea, single superphosphate, and potassium chloride, respectively.

Five days after seeding, seedlings showed uniform emergence and 25 days after emergence (DAE), nitrogen fertilizer was applied at approximately $60 \mathrm{~kg} \mathrm{ha}^{-1} \mathrm{~N}$ using urea. Insecticide application of Chlorpyrifos was performed for control of armyworm (Spodoptera frugiperda) at a dose of approximately $480 \mathrm{~mL} \mathrm{ha}^{-1}$ of active ingredient. Weed control was carried out by manual weeding.

Harvesting was performed when the plants showed grain at the hard dough stage, which was at 95 DAE for grain sorghum cultivars and 105 DAE for cultivars of forage and sweet sorghum. For ensiling, forage was chopped to approximately $20 \mathrm{~mm}$ in length using a stationary forage cutter. The experimental units were experimental silos (glass jars) with a volume of $2.5 \mathrm{~L}$ that were equipped with waterfilled air locks on their lids, which enabled the release of fermentation gases during storage without any ingress of air.

The experimental silos were filled manually with enough forage to obtain a density of $550 \mathrm{~kg} \mathrm{~m}^{-3}$, with approximately $1.375 \mathrm{~kg}$ of green mass per silo. After filling, the silos were closed and a silicone layer was applied at the edges of the lids to ensure complete sealing. The silos remained closed for 30 days.

For forage evaluation, ten plants per plot were collected and chopped to approximately $20 \mathrm{~mm}$ in length using a stationary forage cutter. For silage evaluation, sampling was performed at the experimental silo geometrical center at silo opening, with the upper and lower portions being discharged. After that, the mass was homogenized and a sample was freezedried at $-70{ }^{\circ} \mathrm{C}$ for $48 \mathrm{~h}$. Samples were ground in a Wiley mill until they could pass through a 20 mesh steel sieve.

\section{Chemical characteristics}

For pre-dried samples of forage and silage, analysis was performed for content of dry matter (DM), organic matter, ash, and crude protein $(\mathrm{CP})$ in accordance with procedures of AOAC (1990), and for neutral detergent fiber (NDF) based on methods described by Goering and Van Soest (1970).

Fractionation of protein was completed in accordance with the Cornell Net Carbohydrate and Protein System (Licitra; Hernandez; Van Soest, 1996), where fraction A (non-protein nitrogen-NPN) was determined as the difference between total $\mathrm{N}$ and $\mathrm{N}$ insoluble in trichloroacetic acid (TCA). This was obtained by treating $500 \mathrm{mg}$ of sample with $50 \mathrm{~mL}$ of distilled water for 30 minutes, and then adding another $10 \mathrm{~mL}$ of TCA at a concentration of $10 \%$ for a further 25 minutes. The residue was filtered through a glass filter crucible of porosity 2 (40 to $100 \mu \mathrm{m}$ ) and then washed with TCA at a concentration of $1 \%$. Residue for $\mathrm{N}$ determination was obtained after the material was dried in a non-ventilated oven $\left(105^{\circ} \mathrm{C}\right)$ for $16 \mathrm{~h}$. The $\mathrm{B} 3$ fraction was calculated as the difference between $\mathrm{N}$ insoluble in neutral detergent and $\mathrm{N}$ insoluble in acid detergent, which were determined by heating a $500 \mathrm{mg}$ sample with neutral and acid detergent solution, respectively, for $1 \mathrm{~h}$ in an autoclave. The residues in the bags of non-woven fabric tissue (pore size $100 \mu \mathrm{m}-100 \mathrm{~g} \mathrm{~m}^{-2}$ ) were then transferred to test tubes and analyzed for residual N. Fraction $\mathrm{C}$ was considered as $\mathrm{N}$ insoluble in acid detergent. The fraction $\mathrm{B} 1+\mathrm{B} 2$ was determined as the difference between total $\mathrm{N}$ and the sum of fractions $\mathrm{A}, \mathrm{B} 3$, and $\mathrm{C}$.

Fractionation of carbohydrates was performed based on methods described by Sniffen, O'Connor and Van Soest (1992), where the fiber carbohydrate (FC) was obtained from the NDF corrected for ash and protein content (NDFap); the fraction A, corresponding to the water soluble carbohydrates, was obtained by methodology described by Deriaz (1961); the fraction C, corresponding to the indigestible NDF (iNDF), was obtained after $240 \mathrm{~h}$ of incubation in situ (Casali et al., 2008); the fraction $\mathrm{B} 2$, which corresponds to the available fraction of the fiber, was obtained by the difference between the NDFap and fraction C; and fraction B1 was not calculated because the content of non-fiber carbohydrate + ether extract (NFC + EE) was estimated based on methods described by Hall (2015), using the following equation: $\mathrm{NFC}+\mathrm{EE}=100$ $-(\mathrm{CP}+\mathrm{NDFa}+\mathrm{ash})$, where $\mathrm{NDFa}$ was obtained from the NDF corrected for ash content.

\section{Kinetic parameters and in vitro digestibility of dry matter}

Two incubations were performed based on the methodology described by Pell and Schofield (1993). The preparation of the samples for in vitro incubations was carried out by taking approximately $500 \mathrm{mg}$ of sample material (450 $\mathrm{mg} \mathrm{DM}$ ) and placing in glass flasks with a total volume of $120 \mathrm{~mL}$, in duplicate.

Subsequently, McDougall buffer solution (McDougall, 1949) was added to the flasks; the solution had been previously adjusted to a $\mathrm{pH}$ of 6.9 by flushing with $\mathrm{CO}_{2}$ without oxygen. A freshly prepared reducing solution consisting of $625 \mathrm{mg} \mathrm{L}^{-1} \mathrm{HCl}$-cysteine and $1000 \mathrm{mg} \mathrm{L}^{-1}$ $\mathrm{Na}_{2} \mathrm{SO}_{3}$ was added to the buffer solution. In each flask, $40 \mathrm{~mL}$ of the total solution (buffer solution and reducing 
solution) was added 30 minutes before inoculation, while flushing with $\mathrm{CO}_{2}$ so that anaerobic conditions were ensured. The flasks were maintained in a water bath at $39^{\circ} \mathrm{C}$.

The rumen fluid was collected from two rumencannulated cows that were fed with corn silage plus concentrate in a proportion of 60:40. As roughage, the same forage that was incubated was utilized, and the concentrate was composed of soybean meal, corn, and mineral mixture with $21 \% \mathrm{CP}$ (DM basis). The rumen fluid was obtained from the liquid:solid interface of the rumen environment, and was filtered through a triple layer of cheesecloth, immediately conditioned in a thermal container, and transported to the incubation room under anaerobic conditions.

Next, $10 \mathrm{~mL}$ of ruminal fluid was inoculated into each flask, always under $\mathrm{CO}_{2}$ flushing. The flasks were then immediately sealed with a rubber stopper and aluminum seal, and placed in a $39^{\circ} \mathrm{C}$ water bath with an orbital agitation system (Malafaia et al., 1998). After the flasks were sealed, the gas present inside was released with a needle, and the time until gas pressure equalization occurred was computed.

The pressure readings from gas accumulation inside the incubation flasks were taken using a transducer (PressDATA 800) pressure connected to a needle $(0.7 \mathrm{~mm})$ at the following times: $1,2,3,4,5,6,8,10,12,18,24,36,48$, $60,72,84$, and $96 \mathrm{~h}$ after the start of incubation. To correct the gas volume from the rumen fluid and the buffer solution, four flasks were incubated without a sample (blank); thus, for each reading time, the gas volume of flasks with the sample was subtracted by the volume of flasks without samples.

The gas production data from incubation times were utilized for the construction of cumulative gas production profiles in an Excel spreadsheet, which were applied to estimate the kinetic parameters of sample digestion via the one-pool model proposed by Schofield, Pitt and Pell (1994), represented by the following formula:

Gas $=\mathrm{Vf} /\left(1+\exp \left(2-4 * \mathrm{C}^{*}(\mathrm{~T}-\mathrm{L})\right)\right)$

where, Vf represents the final gas volume $(\mathrm{mL}) ; \mathrm{C}$ is the DM digestion rate $\left(\mathrm{h}^{-1}\right)$; T is the incubation time $(\mathrm{h})$; and $\mathrm{L}$ is the lag time (h).

At the end of the incubation, flasks were removed from the water bath and subjected to $\mathrm{pH}$ measurements with a digital potentiometer.

For in vitro digestibility of dry matter (IVDDM), the incubation residue was filtered under a vacuum in a glass filter crucible of porosity 2 (40 to $100 \mu \mathrm{m})$ and washed with hot distilled water. The residual DM was obtained after the material was dried in a non-ventilated oven $\left(105^{\circ} \mathrm{C}\right)$ for $16 \mathrm{~h}$.

\section{Statistical analyses}

The statistical model applied was $\mathrm{Y}_{\mathrm{ijk}}=\mu+\mathrm{B}_{\mathrm{j}}+\mathrm{C}_{\mathrm{i}}$ $+\mathrm{ea}_{\mathrm{ij}}+\mathrm{P}_{\mathrm{k}}+\mathrm{CP}_{\mathrm{ik}}+\mathrm{eb}_{\mathrm{ijk}}$, where $\mathrm{Y}_{\mathrm{ijk}}=$ value observed in sorghum cultivar $\mathrm{i}$, at crop period $\mathrm{k}$, in block $\mathrm{j} ; \mu=$ overall mean; $B_{j}=$ effect of block $j ; C_{i}=$ effect of sorghum cultivar $\mathrm{i}$; ea $\mathrm{a}_{\mathrm{ij}}=$ random error of plot (error A); $\mathrm{P}_{\mathrm{k}}=$ effect of crop period $\mathrm{k} ; \mathrm{CP}_{\mathrm{ik}}=$ effect of sorghum cultivar and crop period interaction; $\mathrm{eb}_{\mathrm{ijk}}=$ random error of split-plot.

Data were subjected to analysis of variance and the means were compared by the least significant difference (LSD) test, adopting the probability level of $5 \%$, with the SISVAR statistical program, version 5.3.

\section{RESULTS AND DISCUSSION}

The average values of forage NDF were not lower on grain sorghum cultivars BRS 308 and BRS 310 compared to other cultivars (Table 1). The fiber content of forages should be related to the genotype of plants (Di Marco et al., 2009) or the leaf blade:stem+sheath ratio (Elseed; Eldaim; Amasaib, 2007). The low levels of NDF in the forage of sweet sorghum cultivars BRS 506 and CMSXS 647 in the first crop might be due to the high WSC content in these plants, which are characterized by high content of non-structural carbohydrates that remain in the stem and leaves in the form of soluble sugars.

The high NDF content for silage of sweet sorghum cultivars BRS 506 and CMSXS 647 in the first crop (Table 2) was probably because of the higher DM loss within the silo owing to high ethanol and butyric acid production. Gomes et al. (2006) evaluated the chemical composition of sweet sorghum forage and observed an average NDF value of $45.9 \%$ for cultivar BRS 506, which was higher than the results obtained during the present study at both first and second crops. Machado et al. (2012) verified NDF of 54.9 and $52.8 \%$ for forage sorghum cultivar BRS 610 and BRS 655, respectively, which were higher than results observed during the present study.

The WSC metabolism during fermentation of sugar and synthesis of ethanol by yeast can cause an increase in fiber content during ensiling, especially in material with high sugar content (Avila et al., 2009), which occurred during the ensiling of the sweet sorghum cultivars BRS 506 and CMSXS 647 in the first crop.

Sweet sorghum cultivars presented lower ash content, probably because of the higher stem proportion of these cultivars. Elseed, Eldaim and Amasaib (2007) reported that the stems of sorghum plants tend to contain lower levels of ash and silica. 
Table 1: Chemical composition ( $100 \mathrm{~g}^{-1} \mathrm{DM}$ ) of different purpose sorghum forage for ensiling in two crop periods.

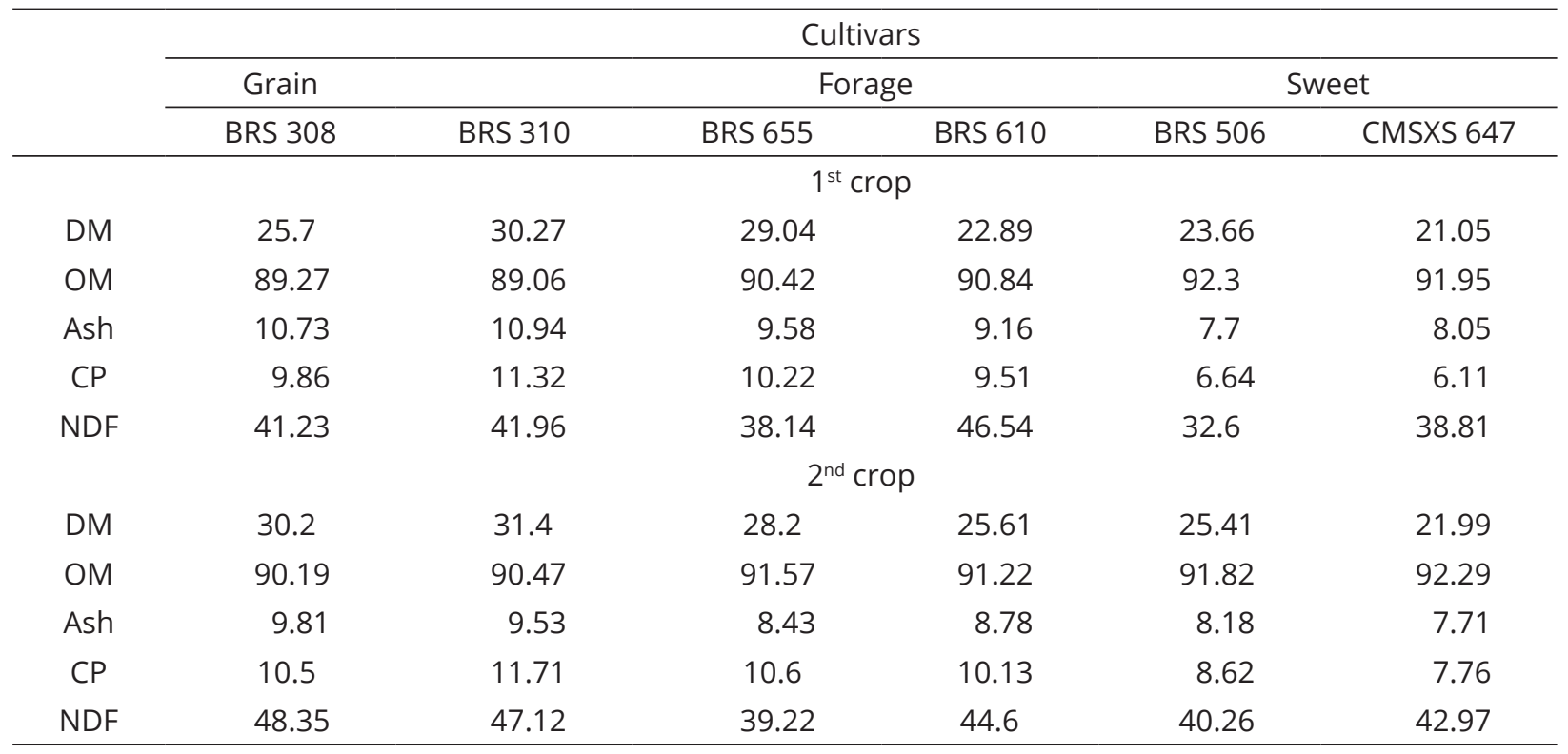

DM: dry matter; OM: organic matter; CP: crude protein; NDF: neutral detergent fiber.

Table 2: Chemical composition (g $100 \mathrm{~g}^{-1} \mathrm{DM}$ ) of different purpose sorghum silage.

\begin{tabular}{|c|c|c|c|c|c|c|c|}
\hline \multirow{3}{*}{ Crop period } & \multicolumn{6}{|c|}{ Cultivars } & \multirow[t]{3}{*}{ Mean } \\
\hline & \multicolumn{2}{|c|}{ Grain } & \multicolumn{2}{|c|}{ Forage } & \multicolumn{2}{|c|}{ Sweet } & \\
\hline & BRS 308 & BRS 310 & BRS 655 & BRS 610 & BRS 506 & CMSXS 647 & \\
\hline \multicolumn{8}{|c|}{ Organic matter } \\
\hline $1^{\text {st }}$ crop & 90.08 & 91.61 & 92.20 & 92.06 & 93.25 & 93.40 & 92.10 \\
\hline $2^{\text {nd }}$ crop & 91.10 & 90.65 & 92.95 & 92.08 & 93.81 & 93.53 & 92.35 \\
\hline Mean & 90.59 c & $91.13 c$ & $92.58 \mathrm{~b}$ & $92.07 \mathrm{~b}$ & $93.53 \mathrm{a}$ & $93.46 \mathrm{a}$ & \\
\hline CV (\%) & & & & & & & 0.76 \\
\hline \multicolumn{8}{|c|}{ Ash } \\
\hline $1^{\text {st }}$ crop & 9.92 & 8.39 & 7.80 & 7.94 & 6.75 & 6.60 & 7.90 \\
\hline $2^{\text {nd }}$ crop & 8.90 & 9.35 & 7.05 & 7.92 & 9.19 & 6.47 & 7.65 \\
\hline Mean & $9.41 \mathrm{a}$ & $8.87 \mathrm{a}$ & $7.42 \mathrm{~b}$ & $7.93 \mathrm{~b}$ & $6.47 c$ & $6.54 \mathrm{c}$ & \\
\hline CV (\%) & & & & & & & 9.06 \\
\hline \multicolumn{8}{|c|}{ Neutral detergent fiber } \\
\hline $1^{\text {st }}$ crop & $38.19 \mathrm{cB}$ & $39.14 \mathrm{CA}$ & $42.42 \mathrm{cA}$ & $48.36 \mathrm{bA}$ & $48.47 \mathrm{bA}$ & $53.85 \mathrm{aA}$ & 45.07 \\
\hline $2^{\text {nd }}$ crop & $50.96 \mathrm{aA}$ & $43.31 \mathrm{bA}$ & 37.08 cB & 39.98 bcB & $40.61 \mathrm{bcB}$ & $44.41 \mathrm{bB}$ & 42.72 \\
\hline Mean & 44.58 & 41.23 & 39.75 & 44.17 & 44.54 & 49.13 & \\
\hline CV (\%) & & & & & & & 7.96 \\
\hline
\end{tabular}


For carbohydrate fractions, silages of sweet sorghum cultivars BRS 506 and CMSXS 647 had higher levels of the carbohydrate fraction A, which consisted of WSC (Table 3). This was possibly because of the ability of this cultivar to store soluble sugars in its leaves and stems. However, the relatively low WSC content for the silage of sweet sorghum cultivar CMSXS 647 in the first crop might be due to the high alcoholic and butyric fermentation inside the silo. Zhang et al. (2016) reported higher WSC levels in silages of sweet sorghum cultivar Rio $(6.99 \%$ of WSC) than in forage sorghum cultivar X096 (4.88\% of WSC), with a response pattern similar to that observed in the present study.
The higher values of estimated NFC + EE observed for grain sorghum cultivars BRS 308 and BRS 310 and forage sorghum cultivar BRS 655 in the first crop might have occurred because of the greater proportion of panicles, with higher amounts of grains, that are rich in NFC and EE. Orrico Junior et al. (2015) evaluated the chemical composition of sweet sorghum cultivars and observed panicle proportions of $11.5 \%$ due to its physiology, while Kaiser et al. (2004) showed that grain sorghum had the potential to produce high-quality silage, with 40 to $50 \%$ of grain in the silage. Santos et al. (2013) investigated the agronomic characteristics of sorghum for ensiling and reported average panicle proportions of $7.0,41.0$, and $50.2 \%$ for sweet sorghum

Table 3: Content of carbohydrates ( $100 \mathrm{~g}^{-1} \mathrm{DM}$ ) in silages of different purpose sorghum cultivars.

\begin{tabular}{|c|c|c|c|c|c|c|c|}
\hline \multirow{3}{*}{ Crop period } & \multicolumn{6}{|c|}{ Cultivars } & \multirow[t]{3}{*}{ Mean } \\
\hline & \multicolumn{2}{|c|}{ Grain } & \multicolumn{2}{|c|}{ Forage } & \multicolumn{2}{|c|}{ Sweet } & \\
\hline & BRS 308 & BRS 310 & BRS 655 & BRS 610 & BRS 506 & CMSXS 647 & \\
\hline \multicolumn{8}{|c|}{ WSC } \\
\hline $1^{\text {st }}$ crop & 6.31 bcA & $5.69 \mathrm{bcA}$ & $8.17 \mathrm{abA}$ & $4.67 \mathrm{cA}$ & $10.40 \mathrm{aA}$ & 7.19 bB & 7.07 \\
\hline $2^{\text {nd }}$ crop & $4.54 \mathrm{cA}$ & $5.24 \mathrm{cA}$ & $8.07 \mathrm{bA}$ & $4.55 \mathrm{cA}$ & $12.81 \mathrm{aA}$ & $11.01 \mathrm{aA}$ & 7.70 \\
\hline Mean & 5.42 & 5.46 & 8.11 & 4.61 & 11.60 & 9.10 & \\
\hline $\mathrm{CV}$ & & & & & & & 22.91 \\
\hline \multicolumn{8}{|c|}{$\mathrm{NFC}+\mathrm{EE}$} \\
\hline $1^{\text {st }}$ crop & $43.70 \mathrm{abA}$ & $43.14 \mathrm{abA}$ & $44.60 \mathrm{aA}$ & 38.26 bcA & $40.47 \mathrm{abcB}$ & $35.70 \mathrm{cB}$ & 40.98 \\
\hline $2^{\text {nd }}$ crop & $32.39 \mathrm{bB}$ & $37.82 \mathrm{bA}$ & $47.00 \mathrm{aA}$ & $43.81 \mathrm{aA}$ & $47.87 \mathrm{aA}$ & $44.25 \mathrm{aA}$ & 42.19 \\
\hline Mean & 38.05 & 40.48 & 45.80 & 41.03 & 44.17 & 39.98 & \\
\hline CV & & & & & & & 9.28 \\
\hline \multicolumn{8}{|c|}{ Fraction B2 } \\
\hline $1^{\text {st }}$ crop & $12.43 \mathrm{bB}$ & 14.04 bB & $15.06 \mathrm{bA}$ & $20.77 \mathrm{aA}$ & $21.62 \mathrm{aA}$ & $23.20 \mathrm{aA}$ & 19.85 \\
\hline $2^{\text {nd }}$ crop & $22.48 \mathrm{aA}$ & 19.49 aA & $12.14 \mathrm{bA}$ & $12.83 \mathrm{bB}$ & $20.69 \mathrm{aA}$ & $23.55 \mathrm{aA}$ & 18.53 \\
\hline Mean & 17.46 & 16.77 & 13.60 & 16.80 & 21.16 & 23.37 & \\
\hline $\mathrm{CV}$ & & & & & & & 19.39 \\
\hline \multicolumn{8}{|c|}{ iNDF } \\
\hline $1^{\text {st }} \mathrm{crop}$ & $22.12 \mathrm{bA}$ & $21.79 \mathrm{bA}$ & $24.38 \mathrm{abA}$ & $24.69 \mathrm{abA}$ & $24.23 \mathrm{abA}$ & $27.96 \mathrm{aA}$ & 24.19 \\
\hline $2^{\text {nd }}$ crop & $25.27 \mathrm{aA}$ & $21.18 \mathrm{abA}$ & $22.66 \mathrm{abA}$ & $25.29 \mathrm{aA}$ & $17.94 \mathrm{bB}$ & $19.10 \mathrm{bB}$ & 21.91 \\
\hline Mean & 23.70 & 20.49 & 23.52 & 24.99 & 21.08 & 23.53 & \\
\hline $\mathrm{CV}$ & & & & & & & 14.25 \\
\hline
\end{tabular}

CV: Coefficient of variation; WSC: water soluble carbohydrate; NFC + EE: estimated non-fiber carbohydrate and ether extract, based on methods described in Hall (2015); Fraction B2: fraction of potentially digestible fiber, obtained by the difference between NDFap and iNDF; iNDF: indigestible neutral detergent fiber.

* Means followed by the same capital letter in the column and by small letters in the row do not differ among themselves by LSD test $(p>0.05)$. 
cultivars BRS 506 and forage sorghum cultivar BRS 610 and BRS 655, respectively.

In the second crop, this response pattern was not observed. The weather conditions of decreasing rainfall (Figure 1) during this crop period might have decreased the plant grain filling, which reduced the proportion of NFC in grain sorghum cultivars BRS 308 and BRS 310 compared to the first crop. When comparing the production of corn at different crop seasons in Goiás, Heinemann et al. (2009) observed yield loss lower than 50\% in the first crop and higher than $50 \%$ in the second crop, which was due to water deficiency during the grain filling phase.

Concerning the crop period, the sweet sorghum cultivars BRS 506 and CMSXS 647 had higher levels of estimated NFC + EE in the second crop compared to the first, probably because of the higher average values of WSC content observed. The forage sorghum cultivar BRS 655 always presented higher levels of estimated $\mathrm{NFC}+\mathrm{EE}$, indicating greater proportion of panicles in the plant. Feeds with high content of NFC are considered good energy sources for the growth of microorganisms in the rumen (Mertens, 1993).

The lower levels of fraction B2 observed for silages of grain sorghum cultivars BRS 308 and BRS 310 and forage sorghum cultivar BRS 655 in the first crop might be due to a higher proportion of panicles, with lower NDF content. The NDF values are usually linked to the values of fraction B2 of carbohydrates in forages. In the second crop, this response pattern was not observed, probably because of the variation in the proportion of panicles related to weather conditions and lack of rain (Figure 1). The fraction $\mathrm{B} 2$ is potentially digestible fiber in the rumen (Sniffen; O'Connor; Van Soest, 1992); however, Russell et al. (1992) reported that roughage containing high contents of carbohydrates fraction B2 requires greater NPN levels to meet the $\mathrm{N}$ requirements of the structural carbohydrates fermenting microorganisms.

Silages of grain sorghum cultivars BRS 308 and BRS 310 presented lower levels of iNDF than did the forage and sweet cultivars BRS 506 and CMSXS 647 in the first crop, possibly due to the higher proportion of panicles and consumption of carbohydrate soluble fraction observed in the sweet sorghum cultivars. In the second crop, the sweet sorghum cultivars BRS 506 and CMSXS 647 had lower iNDF content than the other cultivars did. In sweet sorghum cultivars, the higher iNDF content in the first crop than in the second crop might be due to an increase of fiber content with the alcoholic fermentation observed for these cultivars. Di Marco et al. (2009) tested the silage nutritional value of different purpose sorghum and observed higher lignin content in grain sorghum cultivars AG1809 than in sweet sorghum AG200, which can promote lower digestibility.

The iNDF is comprised of a fraction of the plant cell wall that is not digested along the gastrointestinal tract (Sniffen; O'Connor; Van Soest, 1992). Huhtanen, Nousiainen and Rinne (2006) reported that lignin is related to the iNDF and its content can be estimated by a conversion factor $(2.4 \times$ lignin content $)$. However, these authors demonstrated that the iNDF content obtained with the in situ incubation method had a better relationship with the digestibility of feed OM.

The lower CP levels observed in the sweet sorghum cultivars BRS 506 and CMSXS 647 (Table 4) were because of the higher height and lower proportion of panicles. Good silage should have a minimum CP content of approximately $7.0 \%$ so that DM intake is not influenced (Van Soest, 1994). Such values were not observed for silages of sweet sorghum cultivars in both crops. Zhang et al. (2015) stated that the CP content of sweet sorghum silages is insufficient to meet the minimum requirements of ruminants. Undersander et al. (1990) showed that silages of sorghum harvested at the soft dough stage of development contains 8 to $12 \% \mathrm{CP}$.

Nascimento et al. (2008) observed CP content of $10.98 \%$ for grain sorghum cultivar Arakan. Albuquerque et al. (2013) evaluated the chemical composition of forage sorghum and observed an average $\mathrm{CP}$ content of $6.22 \%$ for cultivar BRS 610. Zhang et al. (2016) reported average levels of $6.73 \% \mathrm{CP}$ for sweet sorghum silages. These response patterns are similar to those observed in the present study.

Regarding protein fractionation, the higher levels of protein fraction A based on DM, comprised by NPN, observed in grain sorghum cultivars BRS 308 and BRS 310 was probably due to the higher CP content of these cultivars. However, the higher levels of protein fraction A based on CP (Table 5) observed in the silages of sweet sorghum cultivars BRS 506 and CMSXS 647 and forage sorghum cultivar BRS 610 are probably due to the lower presence of grains in the mass, since in the sorghum grain a portion of the protein is in the form of a dense protein matrix (Rooney; Pflugfelder, 1986) instead of NPN.

During fermentation inside the silo, a portion of the protein is converted into NPN by proteolysis (Davies et al., 1998). Thus, as part of the protein might not be broken down, the fraction A content based on the CP content should be lower in cultivars with higher proportions of grain. Feed containing NPN is critical to the proper functioning of the rumen as ammonia serves as a source of 
$\mathrm{N}$ for structural carbohydrates fermenting microorganisms. However, high NPN content can result in N loss if there is not a readily available carbon skeleton for synthesis of microbial protein (Russell et al., 1992).

Grain sorghum cultivars BRS 308 and BRS 310 and forage sorghum cultivar BRS 655 presented higher contents of protein fraction $\mathrm{B} 1+\mathrm{B} 2$ (soluble and insoluble true protein) based on CP, possibly because of the higher proportion of grain in these cultivars. The protein fraction $\mathrm{B} 1+\mathrm{B} 2$ presents faster ruminal degradation rates than the fraction B3, and is more likely to be degraded in the rumen, thereby assisting the $\mathrm{N}$ supply for rumen microorganisms (Sniffen; O’Connor; Van Soest, 1992).

The higher levels of protein fraction B3 in silages of sweet sorghum cultivar BRS 506 and grain sorghum cultivars BRS 308 and BRS 310 than in the other cultivars indicates a higher fraction of protein leaking into the animal intestine (Table 5). This fraction is represented by protein bound to the cell wall, with slow rates of degradation, and is mainly digested in the intestines

Table 4: Protein fractionation (g $100 \mathrm{~g}^{-1} \mathrm{DM}$ ) on silages of different purpose sorghum cultivars.

\begin{tabular}{|c|c|c|c|c|c|c|c|}
\hline \multirow{3}{*}{ Crop period } & \multicolumn{6}{|c|}{ Cultivars } & \multirow[t]{3}{*}{ Mean } \\
\hline & \multicolumn{2}{|c|}{ Grain } & \multicolumn{2}{|c|}{ Forage } & \multicolumn{2}{|c|}{ Sweet } & \\
\hline & BRS 308 & BRS 310 & BRS 655 & BRS 610 & BRS 506 & CMSXS 647 & \\
\hline \multicolumn{8}{|c|}{ Crude protein } \\
\hline $1^{\text {st }}$ crop & $10.75 \mathrm{aA}$ & $11.28 \mathrm{aA}$ & 7.07 bcB & $7.47 \mathrm{bB}$ & $6.11 \mathrm{cdA}$ & $5.88 \mathrm{dA}$ & 8.09 \\
\hline $2^{\text {nd }}$ crop & $9.86 \mathrm{bA}$ & $11.32 \mathrm{aA}$ & $10.22 \mathrm{bA}$ & $9.51 \mathrm{bA}$ & $6.64 \mathrm{cA}$ & $6.11 \mathrm{cA}$ & 8.94 \\
\hline Mean & 10.31 & 11.30 & 8.64 & 8.49 & 6.37 & 6.00 & \\
\hline CV (\%) & & & & & & & 7.72 \\
\hline \multicolumn{8}{|c|}{ Fraction A } \\
\hline $1^{\text {st }}$ crop & $4.37 \mathrm{aA}$ & $3.93 \mathrm{abB}$ & $1.68 \mathrm{~dB}$ & $3.38 a b c B$ & $2.91 \mathrm{cA}$ & $2.94 \mathrm{bcA}$ & 3.20 \\
\hline $2^{\text {nd }}$ crop & $4.77 \mathrm{abA}$ & $5.76 \mathrm{aA}$ & $3.96 \mathrm{bcA}$ & $5.14 \mathrm{aA}$ & $3.36 \mathrm{cA}$ & $3.30 \mathrm{cA}$ & 4.38 \\
\hline Mean & 4.57 & 4.85 & 2.82 & 4.26 & 3.14 & 3.12 & \\
\hline CV (\%) & & & & & & & 18.03 \\
\hline \multicolumn{8}{|c|}{ Fraction $\mathrm{B} 1+\mathrm{B} 2$} \\
\hline $1^{\text {st }}$ crop & $5.29 \mathrm{bA}$ & $5.98 \mathrm{aA}$ & 4.29 cB & $3.21 \mathrm{~dB}$ & $2.37 \mathrm{eA}$ & $2.29 \mathrm{eA}$ & 3.90 \\
\hline $2^{\text {nd }}$ crop & $4.00 \mathrm{cB}$ & $4.72 \mathrm{bB}$ & $5.33 \mathrm{aA}$ & $3.72 \mathrm{cA}$ & $2.60 \mathrm{dA}$ & $2.31 \mathrm{dA}$ & 3.78 \\
\hline Mean & 4.64 & 5.35 & 4.81 & 3.47 & 2.49 & 2.30 & \\
\hline CV (\%) & & & & & & & 7.98 \\
\hline \multicolumn{8}{|c|}{ Fraction B3 } \\
\hline $1^{\text {st }}$ crop & 0.51 & 0.68 & 0.28 & 0.36 & 0.49 & 0.29 & $0.44 \mathrm{~A}$ \\
\hline $2^{\text {nd }}$ crop & 0.39 & 0.25 & 0.14 & 0.12 & 0.28 & 0.11 & $0.22 \mathrm{~B}$ \\
\hline Mean & $0.45 a$ & $0.47 a$ & $0.21 \mathrm{~b}$ & $0.24 \mathrm{~b}$ & $0.39 a$ & $0.20 \mathrm{~b}$ & \\
\hline CV (\%) & & & & & & & 31.77 \\
\hline \multicolumn{8}{|c|}{ Fraction C } \\
\hline $1^{\text {st }}$ crop & 0.57 & 0.68 & 0.82 & 0.51 & 0.33 & 0.37 & 0.55 \\
\hline $2^{\text {nd }}$ crop & 0.70 & 0.59 & 0.79 & 0.52 & 0.40 & 0.40 & 0.57 \\
\hline Mean & $0.63 b$ & $0.63 b$ & $0.80 \mathrm{a}$ & $0.52 c$ & $0.36 \mathrm{~d}$ & $0.38 \mathrm{~d}$ & \\
\hline CV (\%) & & & & & & & 15.82 \\
\hline
\end{tabular}


(Sniffen; O’Connor; Van Soest, 1992). Silage of forage sorghum cultivar BRS 655 had higher content of protein fraction $\mathrm{C}$, which indicates that this cultivar had a higher proportion of indigestible protein, that is not utilized for microbial growth or as a source of true protein in the post-rumen digestive tract of ruminants. This fraction, which is comprised of protein associated with lignin, has a high resistance to mammalian and microbial enzymes (Krishnamoorthy et al., 1983).

The lower NPN content and higher levels of protein fractions $\mathrm{B} 1+\mathrm{B} 2$ and $\mathrm{B} 3$ in the first crop than in the second crop might be due to a higher proportion of panicles and grains, since the average rainfall values decreased during the second crop period (Figure 1), which probably affected grain filling.
Regarding feed digestibility, silages of sweet sorghum cultivars BRS 506 and CMSXS 647 presented higher IVDDM than the other cultivars (Table 6), probably because of the higher level of WSC and lower content of iNDF. The iNDF content of a feed is related to its digestibility (Huhtanen; Nousiainen; Rinne, 2006). Amer et al. (2012) reported higher lignin content and lower WSC levels and IVDDM in silages of forage sorghum cultivar CFSH-30 compared to sweet sorghum cultivar CSSH-45, which is similar to the data obtained in the present study. Di Marco et al. (2009) observed higher lignin contents and lower IVDDM in silage of grain sorghum cultivars than in sweet sorghum silages. Orrico Junior et al. (2015) observed IVDDM of $57.3 \%$ for cultivar sweet sorghum BRS 506, which was similar to values observed in the first crop, while Machado et al. (2012) verified IVDDM of 54.5

Table 5: Protein fractionation ( $\mathrm{g} 100 \mathrm{~g}^{-1} \mathrm{CP}$ ) on silages of different purpose sorghum cultivars.

\begin{tabular}{|c|c|c|c|c|c|c|c|}
\hline \multirow{3}{*}{ Crop period } & \multicolumn{6}{|c|}{ Cultivars } & \multirow[t]{3}{*}{ Mean } \\
\hline & \multicolumn{2}{|c|}{ Grain } & \multicolumn{2}{|c|}{ Forage } & \multicolumn{2}{|c|}{ Sweet } & \\
\hline & BRS 308 & BRS 310 & BRS 655 & BRS 610 & BRS 506 & CMSXS 647 & \\
\hline \multicolumn{8}{|c|}{ Fraction A } \\
\hline $1^{\text {st }}$ crop & 40.56 & 34.66 & 23.50 & 45.31 & 47.84 & 49.98 & $40.31 \mathrm{~B}$ \\
\hline $2^{\text {nd }}$ crop & 48.16 & 50.78 & 38.62 & 54.09 & 50.59 & 53.85 & $49.35 \mathrm{~A}$ \\
\hline Mean & $44.36 \mathrm{~b}$ & $42.72 b$ & $31.06 \mathrm{c}$ & $49.70 \mathrm{a}$ & $49.22 \mathrm{a}$ & $51.91 \mathrm{a}$ & \\
\hline CV (\%) & & & & & & & 8.79 \\
\hline \multicolumn{8}{|c|}{ Fraction $\mathrm{B} 1+\mathrm{B} 2$} \\
\hline $1^{\text {st }} \mathrm{crop}$ & 49.33 & 53.20 & 60.85 & 42.97 & 38.71 & 38.84 & $47.32 \mathrm{~A}$ \\
\hline $2^{\text {nd }}$ crop & 40.76 & 41.76 & 52.26 & 39.15 & 39.19 & 37.86 & $41.83 \mathrm{~B}$ \\
\hline Mean & $45.04 \mathrm{~b}$ & $47.48 \mathrm{~b}$ & 56.56 a & $41.06 \mathrm{c}$ & $38.95 \mathrm{c}$ & $38.35 \mathrm{c}$ & \\
\hline CV (\%) & & & & & & & 7.54 \\
\hline \multicolumn{8}{|c|}{ Fraction B3 } \\
\hline $1^{\text {st }}$ crop & 4.81 & 6.00 & 4.05 & 4.86 & 8.06 & 4.86 & $5.44 \mathrm{~A}$ \\
\hline $2^{\text {nd }}$ crop & 3.97 & 2.23 & 1.39 & 1.21 & 4.29 & 1.79 & $2.48 \mathrm{~B}$ \\
\hline Mean & $4.39 \mathrm{~b}$ & $4.11 \mathrm{bc}$ & $2.72 \mathrm{~d}$ & $3.03 \mathrm{~cd}$ & $6.18 \mathrm{a}$ & $3.32 \mathrm{bcd}$ & \\
\hline CV (\%) & & & & & & & 30.09 \\
\hline \multicolumn{8}{|c|}{ Fraction C } \\
\hline $1^{\text {st }}$ crop & $5.30 \mathrm{cB}$ & $6.14 \mathrm{bcA}$ & $11.60 \mathrm{aA}$ & $6.85 \mathrm{bA}$ & $5.38 \mathrm{cA}$ & $6.32 \mathrm{bcA}$ & 6.94 \\
\hline $2^{\text {nd }}$ crop & $7.11 \mathrm{abA}$ & $5.23 \mathrm{cA}$ & $7.73 \mathrm{aB}$ & $5.56 \mathrm{cA}$ & $5.94 \mathrm{bcA}$ & $6.50 \mathrm{abcA}$ & 6.34 \\
\hline Mean & 6.21 & 5.69 & 9.67 & 6.21 & 5.66 & 6.41 & \\
\hline CV (\%) & & & & & & & 13.58 \\
\hline
\end{tabular}


and $53.9 \%$ for forage sorghum cultivar BRS 610 and BRS 655 , respectively, which is lower than those observed in the present study, probably due to the higher NDF content verified by them.

The higher final gas volumes (GV) obtained by sweet sorghum cultivars BRS 506 and CMSXS 647 and the forage sorghum cultivar BRS 655 than the other cultivars might be due to higher WSC content present in these cultivar silages than in the other cultivars. Gas is produced when forage carbohydrates are fermented to acetate and butyrate (Amer et al., 2012). Zerbini et al. (2002) evaluated the gas production of sorghum by the in vitro incubation system and observed a positive correlation between soluble sugars and gas production.

Silages of sweet sorghum cultivars BRS 506 and CMSXS 647 presented lower estimated lag time than grain and forage cultivars did, possibly because of the higher levels of WSC and NPN observed in these cultivars. Seo et al. (2010) stated that it is necessary to have sources of protein with fast and medium rumen degradability in diets rich in readily available carbohydrates to increase the synchrony between energy and $\mathrm{N}$ release.

Regarding crop periods, the higher final GV and feed digestion rate in the first crop compared to the second crop might have occurred because of the higher proportion of panicles and higher NFC at this crop period. Farinelli et al. (2003) evaluated the corn production at different crop seasons and observed $76 \%$ and $60 \%$ for ear yield in first and second crops, respectively. The higher IVDDM observed in the second crop might be due to lower average values of iNDF levels observed during this crop period.

Table 6: Kinetic parameters and in vitro digestibility of dry matter.

\begin{tabular}{|c|c|c|c|c|c|c|c|}
\hline \multirow{3}{*}{ Crop period } & \multicolumn{6}{|c|}{ Cultivars } & \multirow[t]{2}{*}{ Mean } \\
\hline & \multicolumn{2}{|c|}{ Grain } & \multicolumn{2}{|c|}{ Forage } & \multicolumn{2}{|c|}{ Sweet } & \\
\hline & BRS 308 & BRS 310 & BRS 655 & BRS 610 & BRS 506 & CMSX & S 647 \\
\hline \multicolumn{8}{|c|}{ In vitro digestibility of dry matter ( $\left.100 \mathrm{~g}^{-1} \mathrm{DM}\right)$} \\
\hline $1^{\text {st }}$ crop & 53.75 & 57.89 & 56.74 & 57.57 & 59.27 & 58.22 & $57.24 \mathrm{~B}$ \\
\hline $2^{\text {nd }}$ crop & 58.92 & 57.01 & 57.18 & 59.36 & 64.45 & 61.51 & $59.74 \mathrm{~A}$ \\
\hline Mean & $56.33 \mathrm{c}$ & $57.45 c$ & $56.96 \mathrm{c}$ & $58.47 \mathrm{bc}$ & $61.86 a$ & 59. $86 a b$ & \\
\hline CV (\%) & & & & & & & 3.63 \\
\hline \multicolumn{8}{|c|}{ Gas volume (mL $\left.100 \mathrm{mg}^{-1} \mathrm{DM}\right)$} \\
\hline $1^{\text {st }}$ crop & 17.62 & 18.65 & 20.09 & 18.66 & 19.11 & 18.60 & $18.79 \mathrm{~A}$ \\
\hline $2^{\text {nd }}$ crop & 14.75 & 14.42 & 18.00 & 16.62 & 18.58 & 17.38 & $16.63 \mathrm{~B}$ \\
\hline Mean & $16.18 d$ & $16.54 \mathrm{~d}$ & $19.05 a$ & $17.64 \mathrm{c}$ & $18.85 \mathrm{ab}$ & 17.99 bc & \\
\hline CV (\%) & & & & & & & 4.71 \\
\hline \multicolumn{8}{|c|}{ Digestion rate $\left(\% \mathrm{~h}^{-1}\right)$} \\
\hline $1^{\text {st }}$ crop & 2.02 & 2.34 & 2.27 & 1.73 & 1.87 & 1.53 & $1.96 \mathrm{~A}$ \\
\hline $2^{\text {nd }}$ crop & 1.85 & 1.89 & 2.03 & 1.34 & 1.78 & 1.54 & $1.74 \mathrm{~B}$ \\
\hline Mean & $1.93 \mathrm{~b}$ & $2.11 \mathrm{a}$ & $2.15 \mathrm{a}$ & $1.53 \mathrm{c}$ & $1.83 \mathrm{~b}$ & $1.54 \mathrm{c}$ & \\
\hline CV (\%) & & & & & & & 8.84 \\
\hline \multicolumn{8}{|c|}{ Lag time (h) } \\
\hline $1^{\text {st }}$ crop & 8.03 & 10.69 & 7.65 & 6.58 & 2.79 & 3.91 & $6.61 \mathrm{~A}$ \\
\hline $2^{\text {nd }}$ crop & 5.39 & 7.28 & 8.49 & 6.84 & 1.30 & 2.53 & $5.31 \mathrm{~B}$ \\
\hline Mean & $6.71 \mathrm{~b}$ & $8.99 \mathrm{a}$ & $8.07 a b$ & $6.71 \mathrm{~b}$ & $2.05 \mathrm{c}$ & $3.22 \mathrm{c}$ & \\
\hline CV (\%) & & & & & & & 33.13 \\
\hline
\end{tabular}




\section{CONCLUSIONS}

The silage of forage sorghum cultivar BRS 655 has higher content of non-fiber carbohydrate and lower level of potentially digestible fiber, at both crop period, with high nutritional value. Therefore, forage sorghum cultivar BRS 655 is the most recommended cultivar for silage production. The silages of sweet sorghum have higher in vitro digestibility of dry matter and revealed good quality for ruminant nutrition. However, these cultivars have greater potential if utilized at the second crop.

\section{REFERENCES}

Association of Official Analytical Chemists - AOAC. 1990 Official Methods of Analyses. 15. ed. 1:72-74.

ALBUQUERQUE, C. J. B. et al. Agronomic and bromatological characteristics of vegetative components of forage sorghum. Revista Brasileira de Milho e Sorgo, 12(2):164182, 2013.

AMER, S. et al. Effects of water soluble carbohydrate content on ensiling characteristics, chemical composition and in vitro gas production of forage millet and forage sorghum silages. Animal Feed Science and Technology, 177(1):2329, 2012.

AVILA, C. L. S. et al. Effects of an indigenous and a commercial Lactobacillus buchneri strain on quality of sugar cane silage. Grass and Forage Science, 64(4):384-394, 2009.

BORBA, L. F. P. et al. Nutritive value of different silage sorghum (Sorghum bicolor L. Moench) cultivars. Acta Scientiarum. Animal Sciences, 4(2):123-129, 2012.

CASALI, A. O. et al. Influence of incubation time and particles size on indigestible compounds contents in cattle feeds and feces obtained by in situ procedures. Brazilian Journal of Animal Science, 37(2):335-342, 2008.

DAVIES, D. R. et al. Proteolysis during ensilage of forages varying in soluble sugar content. Journal of Dairy Science, 81(2):444-453, 1998.

DERIAZ, R. E. Routine analysis of carbohydrates and lignin in herbage. Journal of the Science of Food and Agriculture, 12(2):152-160, 1961.

DI MARCO, O. N. et al. Digestibility of forage silages from grain, sweet and bmr sorghum types: Comparison of in vivo, in situ and in vitro data. Animal Feed Science and Technology, 153(3):161-168, 2009.
ELSEED, A. M. A. F.; ELDAIM, N. I. N.; AMASAIB, E. O. Chemical composition and in situ dry matter degradability of stover fractions of five sorghum varieties. Journal of Applied Sciences Research, 3(10):1141-1145, 2007.

FARINELLI, R. et al. Desempenho agronômico de cultivares de milho nos períodos de safra e safrinha. Bragantia, 62(2):235-241, 2003.

GOERING, H. K.; VAN SOEST, P. J. Forage fiber analyses, apparatus, reagents, procedures and some applications. Washington, DC:USDA (Agricultural Handbook, 279), 1970.20p.

GOMES, S. O. et al. Agronomic behavior and forage composition of sorghum cultivars in the State of Ceará. Revista Ciência Agronômica, 37(2) 221-227, 2006.

HALL, M. B. Comparisons of in vitro fermentation and high moisture forage processing methods for determination of neutral detergent fiber digestibility. Animal Feed Science and Technology, 199:127-136, 2015.

HEINEMANN, A. B. et al. Water stress pattern for corn (first and second crop) in the Goiás State and their consequences for the breeding program. Ciência e Agrotecnologia, 33(4):1026-1033, 2009.

HUHTANEN, P.; NOUSIAINEN, J.; RINNE, M. Recent developments in forage evaluation with special reference to practical applications. Agricultural and Food Science, 15(3):293323, 2006.

INMET. Brazilian National Institute of Meteorology 2016. Available in: <http://www.inmet.gov.br/portal/index. php? $r=$ home/page\&page=rede_estacoes_auto_graf $>$. Access in: August 10, 2016.

KAISER, A. G. et al. Successful Silage. Dairy Australia NSW Department of Primary Industries, 2004. 468p.

KRISHNAMOORTHY, U. C. et al. Evaluation of a mathematical model of digesta and in vitro simulation of rumen proteolysis to estimate the rumen undegraded nitrogen content of feedstuffs. British Journal of Nutrition, 50(3):555-568, 1983.

LICITRA, G.; HERNANDEZ, T. M.; VAN SOEST, P. J. Standardization of procedures for nitrogen fractionation of ruminant feeds. Animal Feed Science and Technology, 57(4):347-358, 1996.

MACHADO, F. S. et al. Silage quality of sorghum hybrids in different maturation stages. Arquivo Brasileiro de Medicina Veterinária e Zootecnia, 64(3):711-720, 2012. 
MALAFAIA, P. A. M. et al. Ruminal kinetics of some feeds investigated by gravimetric and metabolic techniques. Brazilian Journal of Animal Science. 27(2):370-380, 1998.

MCDOUGALL, E. I. Studies on ruminal saliva. 1. The composition and output of sheep's saliva. Biochemical Journal. 43(1):99-109, 1949.

MERTENS, D. R. Rate and extent of digestion. In: FORBES, J. M.; FRANCE, J. (eds.) Quantitative aspects of ruminant digestion and metabolism. Wallingford: $C A B$ International, 1993, p.13-51.

NASCIMENTO, W. G. D. et al. Nutritive value of corn and sorghum silages and its influence on dairy cow performance. Brazilian Journal of Animal Science. 37(5):896-904, 2008.

ORRICO JUNIOR, M. A. P. et al. Forage potential and silage quality of four varieties of saccharine sorghum. Pesquisa Agropecuária Brasileira. 50(12):1201-1207, 2015.

PELL, A. N.; SCHOFIELD, P. Computerized monitoring of gas production to measure forage digestion in vitro. Journal of Dairy Science. 76(9):1063-1073, 1993.

ROONEY, L. W.; PFLUGFELDER, R. L. Factors affecting starch digestibility with special emphasis on sorghum and corn. Journal of Animal Science. 63:1607-1623, 1986.

RUSSELL, B. J. et al. A net carbohydrate and protein system for evaluation cattle diets: Ruminal fermentation. Journal of Animal Science. 70:3551-3581, 1992.

SANTOS, R. D. D. et al. Agronomic characteristics of forage sorghum cultivars for silage production in the lower middle San Francisco Valley. Acta Scientiarum. Animal Sciences. 35(1):13-19, 2013.

SCHOFIELD, P.; PITT, R. E.; PELL, A. N. Kinetics of fiber digestion from in vitro gas production. Journal of Animal Science. 72(11):2980-2991, 1994.
SEO, J. K. et al. Effects of synchronization of carbohydrate and protein supply on ruminal fermentation, nitrogen metabolism and microbial protein synthesis in Holstein steers. Asian-Australasian Journal of Animal Sciences. 23(11):1455-1461, 2010.

SNIFFEN, C. J.; O'CONNOR, J. D.; VAN SOEST, P. J. A net carbohydrate and protein system for evaluation cattle diets. II. Carbohydrate and protein availability. Journal of Animal Science. 70(11):3562-3577, 1992.

TILLEY, J. M. A.; TERRY, R. A. A. Two-stage technique for the in vitro digestion of forage crops. Grass and Forage Science. 18(2):104-111, 1963.

UNDERSANDER, D. J. et al. Sorghum-forage. In: Alternative field crops manual. Wisconsin and Minnesota Cooperative Extension, University of Wisconsin, Madison, and University of Minnesota, St. Paul. 1990. p.415-423. Available in: <http://docshare03.docshare.tips/files/4774/47746137. pdf>. Access in: May 12, 2016.

VAN SOEST, P. J. Nutritional ecology of the ruminant. 2.ed. Ithaca: Cornell University Press, 1994. 476p.

ZERBINI, E. et al. Composition and in vitro gas production of whole stems and cell walls of different genotypes of pearl millet and sorghum. Animal Feed Science and Technology. 98(1):73-85, 2002.

ZHANG, S. J. et al. Associative effects of ensiling mixtures of sweet sorghum and alfalfa on nutritive value, fermentation and methane characteristics. Animal Feed Science and Technology. 206:29-38, 2015.

ZHANG, S. J. et al. Chemical composition and in vitro fermentation characteristics of high sugar forage sorghum as an alternative to forage maize for silage making in Tarim Basin, China. Journal of Integrative Agriculture. 15(1):175-182, 2016. 